IRA-International Journal of Technology \& Engineering ISSN 2455-4480; Vol.07, Issue 02 (2017)

Pg. no. 28-34

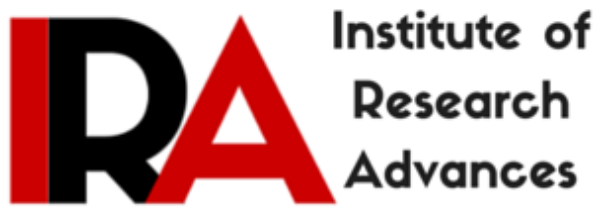

\title{
Mobile Education and Its Impact on Teaching Learning Process of Distance Education
}

\section{Surajit Sarma}

DOEACC B Level, M.Sc.(IT)

Krishna Kanta Handiqui State Open University, India.

Type of Reviewed: Peer Reviewed.

DOI: http://dx.doi.org/10.21013/jte.v7.n2.p3

\section{How to cite this paper:}

Sarma, S. (2017). Mobile Education and Its Impact on Teaching Learning Process of Distance Education. IRA-International Journal of Technology \& Engineering (ISSN 2455-4480), 7(2), 2834. doi:http://dx.doi.org/10.21013/jte.v7.n2.p3

(C) Institute of Research Advances

\section{(cc) BY-NC}

This work is licensed under a Creative Commons Attribution-Non Commercial 4.0 International License subject to proper citation to the publication source of the work.

Disclaimer: The scholarly papers as reviewed and published by the Institute of Research Advances (IRA) are the views and opinions of their respective authors and are not the views or opinions of the IRA. The IRA disclaims of any harm or loss caused due to the published content to any party. 


\section{ABSTRACT}

Education is a lifelong learning process. Education is the backbone of society. In common parlance education is any act or experience that has a formative effect on the mind, character or physical ability of an individual. In this modern era technology has changed the way of teaching learning process. Teaching and learning process has now become more flexible and easily accessible from anywhere and anytime irrespective of location and time and all this is possible because of Mobiles Technology that are being used today. In this paper how Mobile education impact distance education, what are the benefit and challenges it has on teaching-learning process in Distance Education is being discussed. For this paper the data has been collected from internet and other research papers as well as bibliographic. This paper will cover topics on Mobiles Education for Learning, benefits, values, challenges and impact on Distance Learning.

Keywords: Education, Teaching, Learning, Mobile, Distance Education

\section{Introduction}

Mobile learning is the ability to attain knowledge through Personal device like mobile, tablet or laptops. The true definition to mobile learning is still in disputes. Many researchers believe mobile learning to a decedent of e-learning. Mobile learning is often considered as the sub-part of e-learning. Mobile device has the power to make learning accessible and available more widely. It can be considering as the extension of e-learning.

With the development of technology information and communication has become portable than it was a decade ago. In recent years, the Smartphone has become a great tool for people. It is not just a communication tool any more it has become an essential part of human day to day life. Various mobile application has added unlimited facilities to people's life. Now doing banking or booking cars or ordering any product etc. has become so easy and easily accessing because of this mobile application.

As mobile phones and mobile internet like $4 \mathrm{G}$ are affordable can play a great role in development of teaching learning process for students. Young generation students are very much attached with the new mobile technology and would love to use mobiles device for making teaching learning more engaging and personalize it for their particular needs.

A mobile app has the capability to move the operation like music listening, watching video, tweeting and others from the computer to phone.

This paper is aims on utilizing the Mobile for imparting teaching learning to the student of Distance Education. This is the first review of the paper no systematic research has been conducted on the use of Mobile and teaching learning process through Mobile Apps.

\section{Mobile Education Brings Changes Current Education:}

Traditional method of teaching and learning process in the distance education is very poor and in some context embarrassingly low. Literature on the subject of student retention in ODL indicates that even when interventions are designed and undertaken to improve student retention, they tend to fall short. [1]

With use of mobile technology now days teaching learning process in Distance Mode have been developed to a great extent. Now student can have the visual form of class where he/she could visualize the thing that makes the learning more perfect. Mobiles have help to brining the class room to personal 
life. Computer, laptop is not affordable to all but Mobile is portable device that is cheap and easily affordable. With the help of Mobile Apps education could be made fun and exciting by inserting visual graphic, sounds and chatting.

According to Mimi Ito, a cultural anthropologist in the departments of anthropology and informatics at the University of California "Young people learn best when it's relevant to them, when there's social connection tied to it, and when they actually have a personal interest." [2]

Mobile phones can be used for group discussions via text messaging, and since so many cell phones have cameras, they are useful for photography-based projects as well. Students can also record themselves reading stories aloud for writers' workshops or practicing speeches. Many students also use their e-book readers as a replacement for the daily paper, since they can read various editions and magazines on it. Well-known brands include Amazon's Kindle and Barnes \& Noble's Nook [3]

World Wide Web is playing a great role in imparting education in Distance Mode. Almost all Distance Educational Institution and Universities in India are providing course content of Distance Education through Websites. World Wide web is platform Independent and can be used in global scale. Many teacher and lectures are now days using the Website, YouTube video, social networking site, Facebook etc. for teaching purpose.

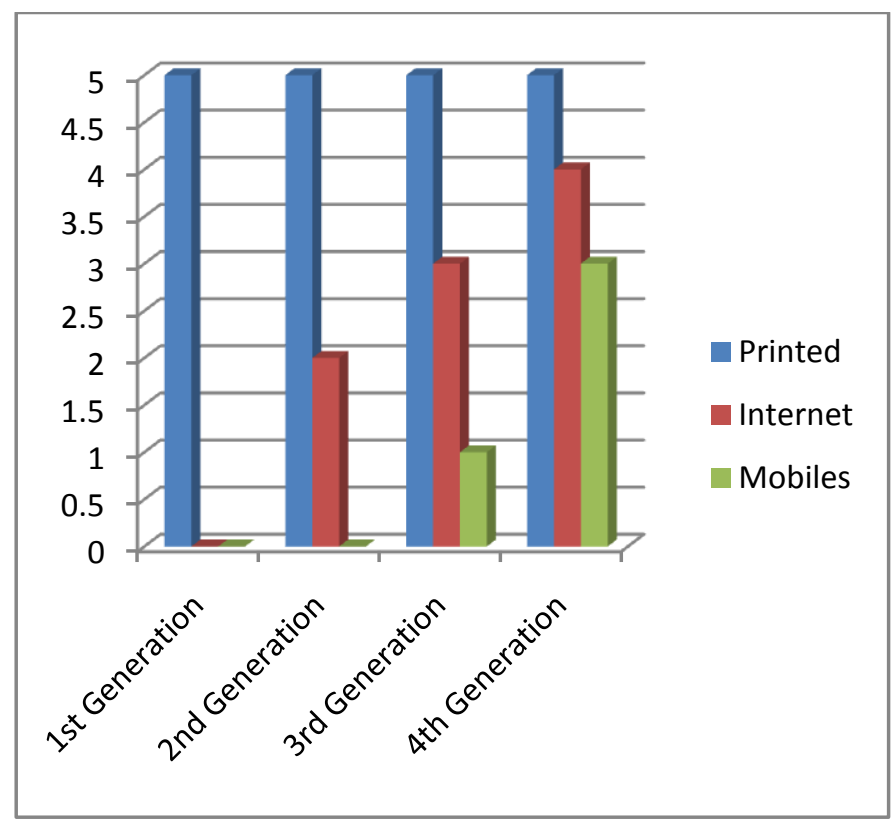

Fig: Generation wise use of Technology in ODL

From the graph we can see that Education through Internet and Mobiles is being growing day by day. Mobile Apps has made it possible to convert the wired learning environment to wireless learning environment. This could be presented diagrammatically as follows: 

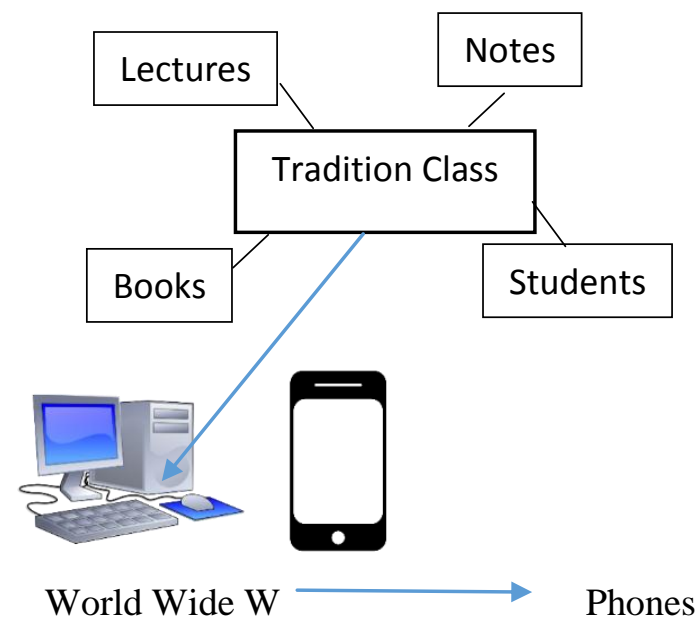

\section{Mobile Learning and Distance Education:}

According to Guha(2003:27) the four elements of flexible learning are accessibility, choice and control, responsibility and support. In order to achieve this technology must be taken into consideration by the learner. Leaner's must have to adopt themselves to the changing digital word.

Now days mobile technologies have become a part of most students and teacher's life. The whole world is going mobile as it can be fit in our pocket and help us to connect to a variety of information from anywhere at any time.

According to Attewell(2005) as quoted by Yousuf(2007) and Becking et al(2008), there are several advantages inherent in mobile learning over internet

- Helps leaner to improve literacy and numeric skills

- Helps learners to recognize their existing abilities

- Can be used for independent and collaborative learning experiences

- Helps learners to identify where they need assistance and support.

- Help to overcome the digital divide.

- Helps to make learning informal.

- Helps learners to be more focused for longer periods.

- Helps to raise self-esteem and self-confidence.

- It is portable form one place to another.

- More wide spread and popular than internet.

- Not much technological pre-requisites.

- Cost is pretty affordable as comparatively less recurring cost and one-time investment.

- Provides real time and location independency. [5]

The problems that are being face by students in distance education can be summarize as follows:

1. Lack of teacher's student contact.

2. Lack of information

3. Lack of popper study support

4. Lack of counseling.

5. Lack of technological knowledge of student.

6. Lack of proper technological infrastructure to impart mobile teaching.

7. Lack of trained personal. 
Mobile learning is an extension of e-learning as such all the facilities that are being provided by the e-learning as well as extra facilities can be provided through mobile technology to the student of distance education. Mobile learning is more interactive, involves more contact, communication and collaboration with people(Vavoula,2005). For example, SMS is a very cost effective means of communication for the student of distance education as important information could be send through sms to the student. Mobile technology can be use by distance leaner to listen to their course lectures, can share or access course materials, notes, assignment and can even make query to their course teachers anytime from anywhere. Mobile technology helps the learners of the distance education to learn thing irrespective of location and time. Leaner in remote areas or in job can continue their study without leaving their jobs or locations. Slow learners can learn at their own pace. Mobile learning also provides learner the facility of choice of learning.

With the use of mobile technology, the today's educator can embrace a learning centered approach to training. The studies have evaluated that imparting Education through Mobile in distance mode certain dimension has be taken into consideration. This dimension could be traced out as follows:

i. Student teacher's interaction.

ii. Course contents

iii. Student to student interaction

iv. Study material and other resources

These dimensions are to be evaluated on the basis of user friendliness, cost effectiveness, technical feasibility.

\section{Different Modes of Mobile Learning for Distance Learning}

The term M-learning stands for mobile learning. It basically refers to sharing or handling of learning resources through mobile technology. M-Learning is characterized by the ability to learn through portable device. Teaching learning process through mobile or other portable devices has their own share of advantages and also disadvantages.

There are many different modes of mobile learning. Some of which has been discussed as follow:

1. SMS: Communication through SMS between two mobiles sharing knowledge and ides.

2. Multimedia SMS: In this technology we can send text sms along with graphics.

3. Social Networking apps: Social Networking apps like facebook, twitter could be used to share information.

4. Wireless internet(3G/4G): Mobiles that have the facility for $3 \mathrm{G} / 4 \mathrm{G}$ internet can play a great role in mobile learning.

5. Bluetooth: Using Bluetooth we can share resources from one mobile to another.

\section{Values of Mobile Learning in Distance Learning}

- Expand Educational opportunities to learners: Mobile learning through mobile apps would help the learners of the Distance Education by providing opportunities to access high quality teaching learning.

- Portability and Inexpensive: Mobile is portable and inexpensive. Student of rural areas could easily afford it.

- Opportunity to disable learners: With integration of various technologies to mobile app like voice, text enlargement, speech to text etc a disable learner could improve his/her learning. 
- Access anytime and anywhere: Learners could access the course content any time anywhere.

- Clarify Ideas and Doubts: Using mobile apps students can get access to various materials to clarify ideas and doubts.

- Elimination of Crisis of teaching staff: Using Mobile Apps for teaching and learning would eliminate the crisis of teaching faculties.

\section{Benefit of Mobile Learning in Distance Learning}

- Provide Easy Access to Study Material anyplace at any time.

- Easily available and affordable.

- Allow learners to collaborate with each other from different locations.

- Provide teacher student interaction

- Encourage self-learning.

- Bring flexibility in learning process.

- Decrease the training cost

\section{Challenges of Mobile Learning in Distance Learning}

- Mobile 3G/4G network Support

- Internet Facility

- Battery life

- Screen Resolution

- Mobile Friendly Support

- Security and Privacy Issue

- Weather condition

- Memory Limits

- Potential for distraction or unethical behavior.

- Parents and teacher's attitude towards mobile learning

- Lack of use of mobile theory of learning.

\section{Different Types of M-Learning for Distance Learning}

○ E-Book

○ PPT

- Web Tutorial

- YouTube Video

- Mp3 Lectures

- Social Media

○ Mobile Apps

\section{Suggestion}

- Encourage student and educator to use mobile education

- Proper training should be given to student how to access study material using mobiles

- Workshop must be organized to make the students aware of mobile learning and their uses.

- Cost effective and user-friendly mobile apps should be developed.

- Proper infrastructure support required.

- Staff must be trained to create effective course content.

- Timely upgradation of course content required. 
- Feedback of the student must be taking into consideration while upgrading the course content.

\section{Conclusion}

Mobile phone is great tool not only for communication it can be a great tool for education also if properly used. With the support of teacher and Mobile the teaching learning could be made very interesting and effective for students of Distance Education. Students can access the study material, listen to the class lectures and can watch video tutorial from any location at any time. Student could also clear their doubt by tweeting or asking queries to their respective teachers through tweet Mobile apps.

Mobile learning can play a great role in imparting quality education in distance mode. The concept of mobile learning will widen in future as more research will be done upon it and I believe in future new ideas, new technologies will be added to the mobile learning and a profound change will occur in Distance Education.

\section{References}

1. Bharat Inder Fozdar \& Lalita S. Kumar ,Mobile Learning and Student Retention,International Review of Research in Open and Distance Learning Volume 8, Number 2: ISSN: 1492$3831,2007$.

2. Edutopia: Mobile Device for learning,The Georg Locaus Education Foundation,2012

3. Pallavi Y. Soman,Mobile learning - An innovative mode in open and distance education,International Journal of Management and Applied Science- ISSN: 2394-7926,2016

4. Guha, A (2003). Information Technology and the Virtual University: A Note. University News, 42(21), 8- 14.

5. Becking, D et al (2008). How to Match Mobile Learning Resources with Learners Current Needs: The Didactic Profiling. http://pi1.fernunihagen.de/publikationen/pub2005.html Retrieved on 31.3.2008.

6. Kuljit Kaur,The Role of M-learning in Distance education, International Journal of Education, Issue June 2016, Vol. 6 